\title{
Geo-political Implications of the Current Economic Crises in the „EURopean Fringe“": From the Mediterranean to the Atlantic Periphery
}

\author{
Damir JosıPovič, Ljubljana*
}

with 2 figures in the text

\section{Content}

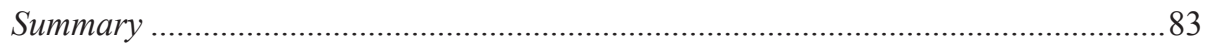

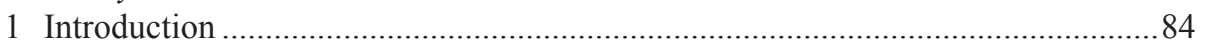

2 The problem of European cleavages and the zone of transition..............................85

3 Analysis - the European fringe or simply the contested South? ...........................8 87

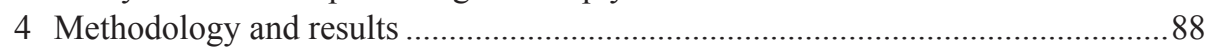

5 Euro, the Eurozone, and the effects of the crisis ................................................. 91

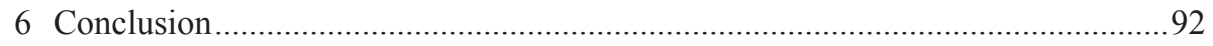

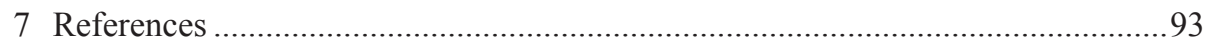

\section{Summary}

The analysis involves a 13 countries comparison in order to include the former Capitalist and Socialist countries, the Old and the New Europe, the countries closer to the core regions, as well as those at the periphery. By comparing a variety of macroeconomic and demographic indicators, the article aims at understanding the impacts of the economic crisis in the light of the recent EU Eastern enlargement. The author concludes that the specific geopolitical legacy of accumulating assets bears a stronger propensity for resilience of a given labour market and thus importantly differentiates the seriousness of crisis. Thus the countries of Central Europe, closer to the European core areas, managed better through the crisis. On the other hand, the peripheral crescent from the Atlantic isles to the Mediterranean Europe is prone * Damir Josipovič, PhD., Scientific Associate, Institute for Ethnic Studies, Ljubljana, Erjavčeva c. 26, SI-1000 Ljubljana, Slovenia; email: damir.josipovic@guest.arnes.si 
to higher indebtedness and less resilient to economic fluctuations inherent in the contemporary capitalism. The Eastern enlargement along with the effects of the crisis significantly contributed to the geopolitical reshaping of Europe.

"Tonight, dreaming is allowed, tomorrow is a new day."

\section{Introduction}

The Eastern enlargement, the so-called Big Bang, substantially changed the European political and economic landscape as the final step of a political transition from the post-war bipolar arrangement. The latter had started imploding years before. Perhaps inspired by Gorbatchev's Perestroika and the hefty support from the West, the Polish and Hungarian first multi-party elections held in 1989 opened the revolutionary year and lead the way to the Berlin Wall collapse - the Iron Curtain melted down. The Europe we used to know was gone. Not only the regimes were washed away, the process involved dissolution of all former Socialist or Communist federal states (Soviet Union, Yugoslavia, Czechoslovakia) with no exceptions. Based essentially on the same principle - self-determination of a given ethno-nationality - both Germanys reunited.

But what were the consequences of such vast and radical changes of the European political map? These rapid changes bore the impression of inevitable, even logical events of complete reorganization of whole countries. The former one- or none-party system Socialism was briskly replaced by multi-party democratic systems with less awareness of the frivol dispersion of market economy and privatization.

"We wanted freedom of speech. We wanted democracy. We wanted to open up. But we certainly did not consider the questions of future economic arrangements. Okay, we wanted some market economy; we also wanted to buy goods for which we formerly had to go to Austria or Italy. But we certainly did not want to destroy a social welfare and to introduce capitalism. We had our vision of our third way - to become a subalpine Switzerland."

This was not a solitary statement. The ideals of reforming the state system were spreading all across the Socialist bloc. In 1980's Poland, for example, the main slogan of Solidarność was: "Socialism - yes, its skewing - no!” (KLeIN 2008, p. 235). The

1 Those were the words of Milan Kučan, the first president of the independent Slovenia, at the proclamation ceremony on 25 June 1991 in Ljubljana.

2 An attendee of the 1990 plebiscite in Slovenia lamented about the situation in 1992 when people were massively losing jobs. Сномкку, for example, presents various cases of discontent with 'like-capitalism', 'predatory capitalism' etc., and the scepticism of population (СНOMSKY 2004, p. 155). 
renowned Polish dissident Adam Michnik later lamented that the worst thing with Communism was what was going to be after it (ibid. p. 243).

25 years after the Berlin Wall was torn down, Europe is facing numerous new challenges. One of the most important is the on-going recession named the $\mathrm{W}$ curve. Exactly one cycle in KondRatiefF's terms was needed for the emergence of a wide public debate on the viability of the current economic system. Since the outbreak of the economic crisis in 2008 there has not been invented anything near the lasting solution. Spawned from the so-called financial bubble, triggered by the real-estate crisis in the United States, the current crisis took over the shape of a deep recession with hardly any reasonable explanation on how to go on.

Many political and other movements arisen after 2008 across Europe, mostly in countries starkly hit by the crisis, concentrated more or less around two major points of view. The first was in line with the direction of the most powerful European countries while the second coquetted with the re-imposition of what was formerly renowned as a state Socialism. In spite of a harsh on-going debate whether austerity measures are able to assure a "new cycle of economic growth", there is rather little effort oriented to developing the ways about how the whole society could be transformed to fit within the paradigm of sustainable development.

Moreover, within the European Union a new approach emerged, which considers indebting rather than excessive austerity. This approach expects that sufficient economic growth would secure enough revenue to refinance the debts and the high interest. As European Union (EU) Commission vice president Jyrki Katainen assures, the so-called "quantitative easing" in the amount of 315 billion Euros will create a healthy business environment to attract private investment and along with the Commission's financial stimulation open new incentives, a new developmental cycle and create new jobs.

The recent approach of the Commission left the question of diminishing natural resources and global warming untackled. At the same time, the political wisdom of president Jean-Claude Juncker reveals both reconciliation with the grand capital holders and the trade unions. As a result, many EU countries found themselves confused in following the steps and advices from the Commission. After almost seven years of 'thin cows' there is not much hope for the proposed scenario to succeed. In the meantime, internal inequalities among European macro-regions are soaring.

\section{The problem of European cleavages and the zone of transition}

While there are several studies on the economic effects of the Eastern geopolitical and economic transition, geographical relationships are rarely critically studied. One recent example is the study of "non-linear geographics and the economics of transition 
and democratization" by Elise BREzIS \& Thierry VERDIER (2013) where the critical factor of temporarily uneven democratization processes is subject to geographical features, such as topography or mere distance:

\begin{abstract}
"One element relatively neglected by this literature is the role of geography and space, and their influences on the evolution of political regimes. This negligence is quite at variance with studies in other social sciences, as anthropologists, economic historians and political scientists have long recognized that geographical and spatial specificities may play an important role in the evolution and emergence of political systems." (ibid. p. 54)
\end{abstract}

Another illustrative example of Adolfo Cristobal-CAmpoAmor \& Osiris Jorge PARCERo (2013) adds up additional dimension as it approaches the "non-linear geographics" by the temporal variable of economic divergence/convergence. In their article, they examine the role of geography and trade liberalization.

"From the beginning of the 1990s to 2005, the Eastern European economic transition has been characterized by a U-shaped pattern of relative development. Initially, relative income per capita between Eastern and Western Europe diverged, but roughly from 1999 onwards, this pattern was reversed and Eastern Europe started to catch up with its Western counterpart." (ibid. p. 871)

They introduced not only the distinction between transition countries of Central and Eastern Europe but also border regions and hinterlands:

“...when analysing the performance inside Eastern Europe, a similar pattern emerges. (Border) initially experienced faster growth than those situated further from the West (Hinterland), but from the end of the 1990s, this was also reversed. A similar pattern can be observed when the attention is focused on industrial output. Hinterland (East) initially suffered a continuous relative deindustrialization, followed by a remarkable recovery from the beginning of the new century." (ibid. p. 872)

Cristobal-CAmpoamor \& PARCero maintain that "literature has typically explained these U-shaped patterns by relying on technological arguments or on the misallocation of factors of production. [...] The existing literature thus puts the emphasis on the intensity of reallocations that were needed to adapt to a superior Western technology, followed by a remarkable catch-up process that was conditioned by redistributive public policies." (ibid. p. 872)

In their study, the two deliberately disregarded issues of technological backwardness or sectorial misallocations. Instead, they proposed an economic geography model where trade liberalization is the only driving force. The rationale 
behind their idea is a belief that the trade reorientation towards the West and the initial deterioration of the market for exports were crucial initial conditions for transition (Cristobal-Campoamor \& Parcero 2013).

While some scholars already anticipated a bloom of geo-economy against geopolitics (e.g. LoRot in Avioutski 2006, p. 22) it is clear that this could only be a case in a virtual and fluid space of the "new economy" (nonmaterial services of financing, informatics and alike).

Although very instructive, the CRistobal-CAmPOAmor \& PARCERo study lacks analysis after the advent of economic recession and crisis. It stops in 2005 when the stage of "cheap money" commenced (STIGLiTz 2010). So, what happened next? Did we witness a prolonged period of convergence, or did the economic crisis strike the East European post-Socialist economic recovery?

\section{Analysis - the European fringe or simply the contested South?}

What is the European fringe? It is a relatively wide space covering a variety of countries and stretching from the Atlantic isles (Iceland, Ireland) all the way to Portugal and Spain at the entrance into the Mediterranean basin. Followed by peninsular and archipelago countries (Italy, Malta, Greece, Cyprus), its main feature is peripheral geographical location in relation to the core of the EU. How to approach methodologically such a varied space? This is exactly one of the aims of the study. Based on the findings of the collaborative FP7 Inspires project, we will now analyse trends in this region in order to embrace as many divisions or cleavages as possible: 'new' vs. 'old' Europe, Catholic vs. Protestant, Atlantic and Mediterranean fringe vs. Central Europe, post-Socialist vs. Capitalist systems, EU vs. non-EU and Euro vs. non-Euro countries, spatial divergence vs. convergence, East vs. West, North vs. South etc. The aim is to find out differences and/or communalities among countries in various fields: position of vulnerable groups of population; unemployment, especially among the younger; standard of living; employment across economic sectors; the extent of corruption etc.

Thus, the analysis involves three of the four post-Socialist Central European "Visegrád" countries of the former Council for Mutual Economic Assistance (COMECON) (Czechia, Slovakia and Hungary). The former Socialist neutral and nonaligned Yugoslavia broke up into seven separate territories. Slovenia became a part of the EU in 2004 within the biggest wave of its enlargement, while Croatia accessed EU in 2013 as its $28^{\text {th }}$ member. Both of them cover a transitional territory between the Mediterranean and Central Europe. Along with the aforementioned three countries of the Visegrád group they represent the so-called 'New Europe', which contrasts with the 
Capitalist countries of the Atlantic fringe (Ireland and Iceland) and the Mediterranean (Portugal, Spain, Italy, Greece).

These countries are supplemented by France as a West European country, and Austria as a Central European country. The inclusion of the latter two is crucial for two main reasons. The first is methodological: the inclusion of countries in different economic, historical and geographical positions contributes to variegated results. The second is geopolitical and in a way arbitrary: the forming of a contingent territory with contours of former political organisations (e.g. former Yugoslavia, Austro-Hungary).

Shortly after Nine-Eleven, Timothy GARTON AsH (2006) wrote that we have got a severe crisis. However important were the consequences of the Nine-Eleven assaults, GARTON Ash maintained that the crisis was suitable for a new (European) beginning. He henceforth stated two important questions for Europe: (1) How much are we prepared to shrink our "economies to preserve our social models? or (2) how much are we prepared to trim down our social model for economic growth?" (2006, p. 213) After 2008, when using the word "crisis" became widely popular and practised every day, this dilemma became seemingly obscured. Through extensive policies of austerity, the EU countries have found themselves increasingly socially stratified (ELLISON 2012).

\section{Methodology and results}

Methodologically we tried to find relationships among countries across the region studied. We omitted any information on the former divide (e.g. Iron Curtain; status of neutrality, engagement etc.). Instead we employed data on environmental issues (electricity, $\mathrm{CO}_{2}$ emissions, arable land etc.), economy (Gross Domestic Product, Gross National Income, agriculture, industries, services etc.), social security (unemployed, youth, women, elderly etc.), and population (fertility, mortality, natural increase etc.).

Let us present two examples of maps with five classes based on a list of 40 indicators. Map processing was done according the JENKS-CASPALL method described in JenKs \& CASPall (1973). The aim was to distinguish five possibly close connections between countries.

The map on electricity consumption (Fig. 1) clearly shows that Iceland is outstanding in terms of consumption and that it does not fit within the studied framework as regards this question. On the other hand there are connections between the Atlantic-Mediterranean countries with an extension to the other extremity (the former Hungarian lands Croatia, Hungary, and Slovakia). Austria, as the next most consuming behind Iceland, remains connected to two other former Austrian lands (Slovenia, Czechia), which consume about the same as highly industrialised France. 
Figure 1: Electricity consumption in $\mathbf{2 0 1 3}$

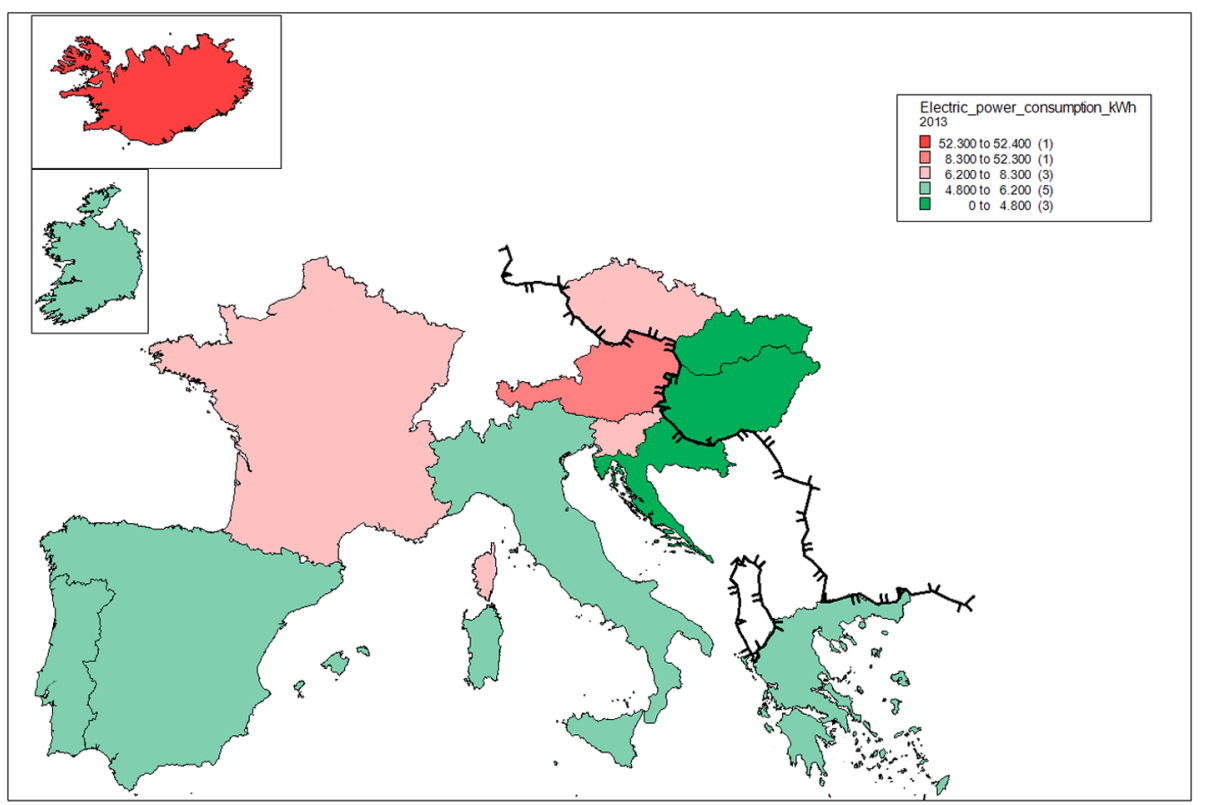

The second map (Fig. 2) shows geographical relationships between countries in terms of budget expenditure per capita. Here, Iceland again is the farthest. Quite surprisingly, the two socially well-developed countries France and Austria are accompanied by the 'Celtic tiger'. This time, the post-Socialist quintet is closely connected to the Mediterranean or Southern European periphery. 
Figure 2: Budget expenditure per capita in 2013

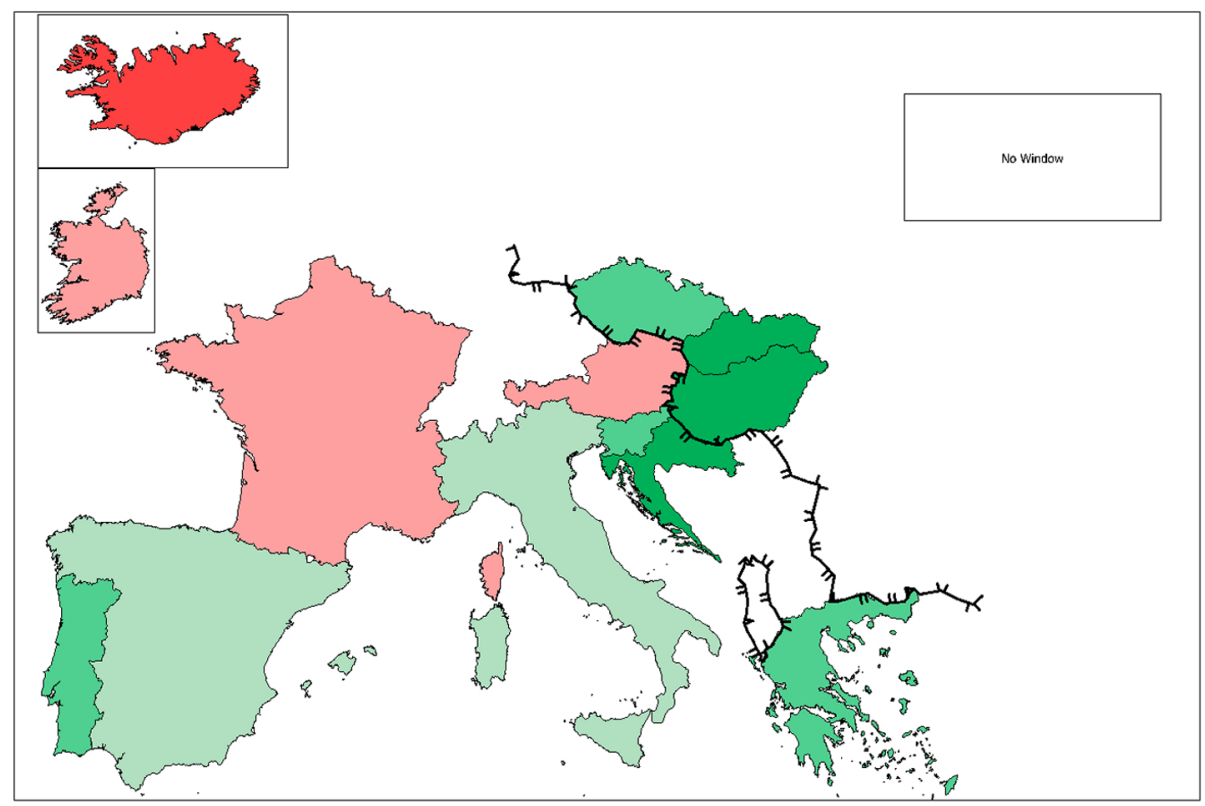

By these two examples it can be seen how complex relationships there might exist. Many more expectedly or unexpectedly divergent and convergent relationships have emerged from the analysis.

To sum the whole range of different indicators up, we employed many reiterations. Based on data hierarchy, standardisation of data to diminish scale-effects, and weighing to reduce the auto-correlation effects, the five-grade cluster based on the internal proximity was synthetized. According to cross-country relationships, group membership is as follows:

1. Austria, Czechia, Hungary, Slovakia, Slovenia

2. Croatia, Greece, Portugal

3. Ireland

4. France, Italy, Spain

5. Iceland

The closest pair of countries is represented by Croatia and Portugal within the second group, and then Slovenia and Czechia within the first group. Another subgroup is represented by Hungary and Slovakia, while Austria is somewhere in between, but more closely linked to Czechia and Slovenia. The next independent pair is Italy and 
Spain within the fourth group. The distance of France to the fourth group equals the distance between groups one and two. Only at the next level, Ireland supplements the first and the second groups, while Iceland was too distant, geographically and socioeconomically, to combine with any of the groups or subgroups.

But can Europe or the European Union survive the growing inequality between countries and regions? In 2015, the countries of the EU have become more segregated than at any time after World War II. The wealthy European North is shrinking and the poor South is spreading to include countries from the former East, but from the Atlantic fringe (after RoKKAN 2000) as well. The former fault line along the Iron Curtain has, in a way, returned to the pivotal European states - most convincingly to Germany. As proposed in RoKKAN (2000, p. 235), the core areas of Western Europe are subject to new cleavages. France, for instance, as one part of the European core duet (alongside Germany) is economically lagging behind Germany and it is therefore worth being studied as well.

Germany - for its gross economic resilience notoriously cited - is on the other hand suffering stark regional disparities. According to BERENTSEN (2016), the western part of Germany invested more than 400 billion German Mark into the former Eastern Germany in the first years after reunification. ${ }^{3}$

\section{Euro, the Eurozone, and the effects of the crisis}

Euro, the common European currency (though not introduced in all of the EU countries) brought among other important benefits (easier trade, retailing, less manipulation for the population etc.) also the potential for transparency. It rendered interstate comparisons within much of the EU more comprehensible, as it omitted the necessity of recalculating exchange rates. The Slovenian economist Mojmir MraK stated in April 2014 that the Eurozone nurtured immense potentials, which remained unexploited. On the contrary, the Eurozone was almost destroyed as the Greek public debt soared to historical heights. The Greek scenario threatened to evolve in all countries of the "European fringe" (Ireland, Portugal, Spain, Italy, Slovenia). It was slowly becoming evident that a common currency can fully serve only if monetary policy is accompanied by fiscal policy.

But it still wasn't the Euro to be blamed for an economic bust (MraK 2014). The Slovenian case shows that the introduction of the Euro on 1 January 2007 coincided

3 In March 2015, the Slovenian media reported that Western Germany's war debt of 36 billion \$ to Yugoslavia was not paid at all. The same was reported for Greece, where the German war debt amounted to 11 billion \$. On the other hand, East Germany had paid all the reparations to the COMECON countries. 
with negotiations for the Public Sector Salary System Act. This Act aimed at a universal system of wages of all public employees in order to make wages comparable. The outcome had shocking financial consequences since the salary mass in the public sector increased nominally by $19.3 \%$ within 24 months. Reduced by inflation, propelled by the introduction of Euro, it was still a 10\% real increase from January 2007 to January 2009 (Josipovič \& Šumi 2013). Spurred by cheap external loans, overdimensioned construction projects pounded to annul the former construction giants like SCT, Primorje, Vegrad and many subjected firms (DRENOVEC 2014). In this way the huge gap in fiscal balance occurred. A yearly loss due to the public salaries' increase complemented by the contracted national economy amounted to $2-3 \%$ of GDP in the years 2008-2013. At the same time, lending became excessively expensive with annuities soaring to $6 \%{ }^{4}$ Thus, the economic decline in Slovenia is better understandable.

Compared to other Central European countries, e.g. the Visegrád group and especially Slovakia that introduced the Euro in January 2009, Slovenia acted more in a 'Mediterranean way'. The debt crisis clearly showed that it approached the politicaleconomic behaviour of Italy or Croatia, for instance. In this way, the former political divides between East and West or Old and New Europe do at least with the present crisis not play a significant role. As much more important appears the role of the traditional North-South divide and, above all, the divide between the European core and its periphery. To take RoKKAN's theory further, it conforms to the institutional and organisational structures existing in Europe (FLORA 2000, pp. 19-20).

It remains to say some words on the Great Eastern Enlargement. The European Union was long considered as an American expository in Europe (e.g. GARTON AsH 2006). Before it could become a world power in itself (If this would ever happen.), the former Eastern Bloc had to deplete. As some saw the enlargement process as a transgression of American style capitalism (cf. STiglitz 2010, p. 218), others look at the new emerging markets primarily as a capital surplus dump or at least a new possibility to invest. Here, the geographer David HARveY goes even further when he says that contemporary capitalism is of such a character that it perpetually amasses capital surpluses in the core areas of the advanced Western countries rather than in the periphery (HARVEY 2011, pp. 211-212).

\section{Conclusion}

Can the joint economic geographical, demographical and geo-political analysis contribute to a new understanding of the European fringe? European fringe is a European periphery stretching from the Atlantic fringe to the Mediterranean EU and to

4 The process of lending under extreme conditions was labelled predatory (see STIGLITz 2010, p. 175). 
the post-Socialist countries of the former East. Such regionalisation is important since it compares countries of varied political and economic legacies. The results confirmed peripherity as the most common denominator in understanding the geo-political and economic position of the countries studied.

The article aimed at reassessing the post-Socialist legacy within the process of EU eastern enlargement. This has been done within the framework of the European fringe - a peripheral crescent around the EU core area. The analysis showed that the eastern EU enlargement shook the very foundation of further socio-economic development since it revealed deep ruptures among states formerly included into the so-called Western geo-political hemisphere. It furthermore argues that despite heavy objections the Eastern enlargement indeed was the greatest achievement in recent EU history although it may seem that the enlargement itself deepened the economic crisis.

Another great achievement was the introduction of a common currency. Though there were strong counter-arguments (e.g. separated fiscal and monetary policies) it seems that the Euro strongly contributed to a more transparent accountancy across the Eurozone. It made the huge inequalities within the EU visible and it re-established the old divides, i.e. core states vs. periphery, especially those between North and South. Under these circumstances the cleavage between the Mediterranean EU, to some extent also the Atlantic fringe and the core France-Germany axis seems to be much more real, than the cleavage towards the former Eastern (Socialist) Europe. The geopolitical positions of Slovenia and Croatia are somewhat controversial. Despite their Socialist past and legacy (though in a version of a self-governing autonomy) their recent transition showed closer resemblance to the Mediterranean geopolitical space.

\section{References}

Avioutskir V. (2006), Géopolitiques continentals - Le monde au XXIe siècle. Paris, Armand Colin.

BERENTSEN W.H. (2016), Geographical impacts of Eastern Germany's inclusion within the EU: 1990-2014. In: Jordan P. (ed.), 10 Years of EU Eastern Enlargement - The Geographical Balance of a Courageous Step. Proceedings of the Symposion in Vienna, 3-4 December 2014 (= ISR-Forschungsberichte, 42), pp. 65-81. Wien, Verlag der Österreichischen Akademie der Wissenschaften.

Brezis E., Verdier T. (2013), Non-linear geographics and the economics of transition and democratization. In: Economics of Transition, 21, 1, pp. 53-71.

Chомsкy N. (2004), Language and Politics. Oakland, AK Press.

Cristobal-Campoamor A., Parcero O.J. (2013), Behind the Eastern-Western European convergence path: the role of geography and trade liberalization. In: Annals of Regional Science, 51, pp. 871-891.

DRENOVEC F. (2014), Kako smo postali kolonija? Delo supplement, 29.03. 
Ellison M. (2012), Reinventing Social Solidarity across Europe. Bristol, Policy Press.

Flora P. (2000), Einführung und Interpretation. In: Flora P. (ed.), Die Theorie Stein Rokkans aus seinem gesammelten Werken rekonstruiert und eingeleitet, pp. 14-119. Frankfurt am Main, Suhrkamp.

Garton Ash T. (2006), Free World. London, Penguin Books.

Harvey D. (2011), The Enigma of Capital. London, Profile Books Ltd.

Huntington S.P. (1993), The clash of civilizations? In: Foreign Affairs, 72, 3, pp. 22-49.

Josipovič D., Šumi I. (2013), National report for Slovenia (= FP7 Inspires project working papers).

KLeIN N. (2008), The Shock Doctrine - the Rise of Disaster Capitalism. New York, Picador.

MraK M. (2014), Če smo v slabem položaju, ni kriva EU. Delo, 28.04.

RoKkan St. (2000), Staat, Nation und Demokratie in Europa. In: Flora P. (ed.), Die Theorie Stein Rokkans aus seinem gesammelten Werken rekonstruiert und eingeleitet, pp. 124412. Frankfurt am Main, Suhrkamp.

Stiglitz J. (2010), Freefall - free markets and the sinking of the global economy. London, Penguin books.

Data sources: Eurostat, OECD, The World Bank, World Development Indicators, Transparency international 